\title{
Lithological mapping and hydrothermal alteration using Landsat 8 data: a case study in ariab mining district, red sea hills, Sudan
}

\author{
Ahmed S.O. Ali *, Amin Beiranvand Pour \\ Universiti Teknologi Malaysia, 81300 UTM Skudai, Johor Bahru, Malaysia \\ *Corresponding author E-mail: a.salah51@hotmail.com
}

Copyright $\odot 2014$ Ahmed S.O. Ali, Amin Beiranvand Pour. This is an open access article distributed under the Creative Commons Attribution License, which permits unrestricted use, distribution, and reproduction in any medium, provided the original work is properly cited.

\begin{abstract}
This study used the ability of remote sensing technology to identify and map the lithological units and alteration zones in a gold mining area in North-eastern Sudan by using Landsat 8 data source. The Landsat data series has been used widely in mapping lithological and altered rocks and in geology in general. The study area contains three gold mines part of Ariab mining district in Red Sea Hills, Northeastern Sudan. There are three types of gold deposits in the study area (Supergene deposits, polymetallic massive sulphide deposits and The Ganaet deposits) are being mined in Hadal Auatib mine, Hassai mine and Kamoeb mine. The objective of this study was to find new high potential areas for gold mineralization in the area. Conventional image processing methods such as (color composite, principle component analysis and band ratio) and minimum noise fraction have been used in this study for the purpose of lithological and alteration zones mapping. The visible and short infrared region was useful for mapping the iron oxides and the clay minerals, in which the thermal bands were used for silicate mapping. The results of this study showed the distribution of the lithological units and the hydrothermal alteration zones along with new high potential areas for gold mineralization which can be used in the future and proved the ability of Landsat data in mapping these feature.
\end{abstract}

Keywords: Landsat-8 Data, Alteration, Lithological Mapping, Gold Exploration, Arabian-Nubian Shield.

\section{Introduction}

The improvement in remote sensing data, interpretation and analysis techniques made the application of lithological mapping and mineral exploration using remote sensing approaches possible. The recognition of the hydrothermal alteration zones by the spectral signature and geological mapping are the main applications in mineral exploration using remote sensing data. Both multispectral and hyperspectral datasets can be used for mapping the alteration zones. Multispectral images can show the altered rocks (clay and iron minerals), where hyperspectral images can be used to show distinctive types of clay and iron rocks [1]. Landsat data has made the evolution of using the satellite images in geological application in the past century. After that came the evolution in the image processing techniques which can be used to enhance the satellite images and show the spectral characteristics of wanted features on the ground.

The ability to discriminate between hydrothermaly altered and unaltered rocks are considerable in mineral exploration studies. In the region of solar reflected light $(0.325$ to $2.5 \mu \mathrm{m})$, many minerals demonstrate diagnostic absorption features due to vibrational overtones, electronic transition, charge transfer and conduction processes [2], [3], [4], [ 5]. The minerals cannot be detected directly from the satellite images, but the appearance of the hydrothermal altered rocks on the image indicate for the existence of iron oxides, sulfide, carbonate or clay minerals under them. The satellite images have the ability to detect the alteration zones by its spectral characteristics. Landsat 8 data can detect the altered rocks and ferrous minerals throw the OLI (Operational Land Imager) part of the image due to the absorption and reflectance characteristics of these rocks which appear in this range. When it came to silicate the two additional thermal bands has the ability to detect the reflectance characteristic for it in their range [6], [7].

Many studies in the past have been introduced in the study area which contain Ariab mining district [8], [9], [10], [11] and in the Arabian-Nubian Shield in general [12], [13]. Ariab mining district consists of polydeformed and 
metamorphosed volcano-sedimentary rocks of the Neoproterozoic Nakasib-Bir Umq Suture [13], [14]. The study area is a part of the Arabian Nubian Shield (ANS), which it exposure of Precambrian crystalline rocks on the flanks of the Red Sea. The Precambrian crystalline rocks are for the most part Neoproterozoic in age. Gold stores and the structure of the Arabian-Nubian Shield have long been a vital acquaintanceship and guarantees to keep on being critical. Gold has been mined from northeast Africa for more than 5000 years [15], [16], and this may be the primary spot where this metal was mined by people. Surely, the expression "Nubia" originates from the Egyptian word for gold [13], [17].

The key elements in minerals exploration are to gain understanding of geologic area through lithological mapping and to assist in defining potential target areas. To map bedrock and identify presence and abundance of specific minerals at specific scale, it is possible to use remote sensing techniques [1]. The study area had received less attention in terms of geological research in the past. However, some projects have been carried out, most of which aim at the appraisal of surface, groundwater resources and mining area structure. Among the researchers are Mansour and Samuel [18], Gabert [19], Cottard [20], Grove [21], Abu Fatima [22]. Suitable image processing techniques are used to extract useful geological information from the Landsat 8 data for arid-semiarid regions. The objective of this study is to conduct a remote sensing investigation for gold exploration to detect the high potential areas for gold mineralization which contain mining district using Landsat 8 image along with a geologic map of the study area. The study area contains the Sudan's Hassai gold mine in North-eastern Sudan as a part of the Proterozoic-aged Ariab greenstone. This study attempted to identify and analyze the role of remote sensing technology and especially Landsat data in lithological mapping and the identification of hydrothermal alteration zones.

\section{Geologic setting}

Sudan contains a part of the East African organic belt. This belt consists of the Mozambique belt and the ArabianNubian Shield (ANS) [23]. The Arabian-Nubian Shield can be found in the countries around the Red Sea. The ArabianNubian Shield (ANS) exposed in Red Sea Hills in North-Eastern Sudan. It was created during the Late Proterozoic accretion of island arcs and back arcs onto the Nile Craton to the east. There are two volcano-sedimentary series which have the same general geological history, Onib-Nafardeib to the north and Ariab-Arbaat-Tokar to the south. These two series was evolving from oceanic crust overlain by mafic volcanics to felsites and epiclastics [20]. There was a development of intense foliation, greenschist metamorphism, and syn- to late stage magmatism caused by the transpressional deformation during the accretion [24]. After that a post-tectonic, sub-aerial appeared which differentiate the emplacement of post-orogenic gabbros and granites throughout the shield and the volcanism in the south. The last stage of evolution in the Arabian-Nubian Shield (ANS) was the Late-stage sinistral wrench faulting [9], [10], [11], [13], and [25].

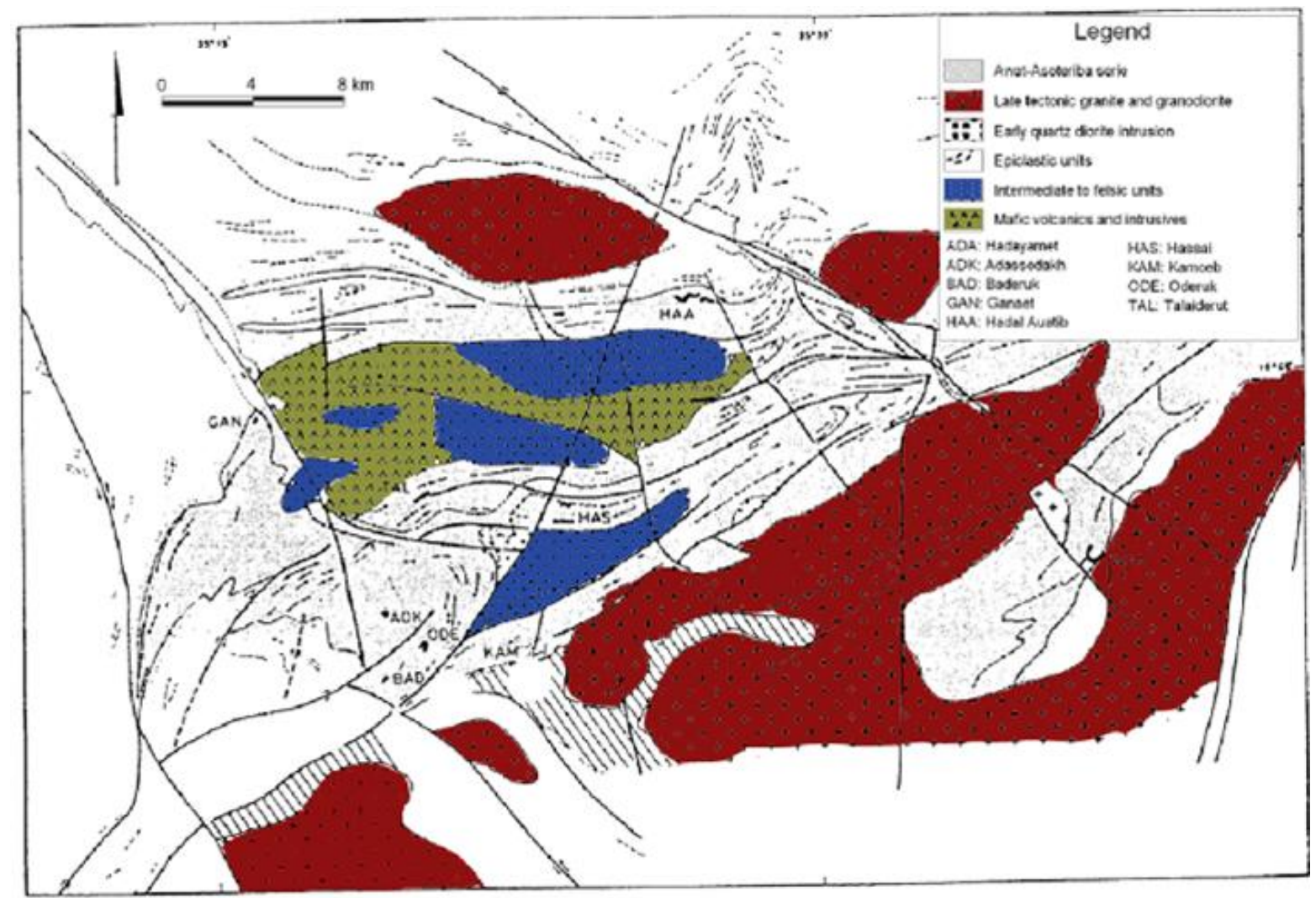

Fig. 1: Geological Map of the Area (Cottard, 1986). 
The study area which contains Ariab mining district has been introduced geologically by Cottard in 1986 [9] as a geological map (Fig1). The host rocks of the study area consist of greywackes intruded by late granites, basic and acidic volcanic rocks, sedimentary rocks and tuffs. In term of gold types that is being mined from the area, there are three types (Supergene deposits with gossans and silica-barite rocks (SBR) and polymetallic massive sulphide deposits, Goldbearing quartz and The Ganaet deposits). The area contains tow faults, the first was responsible for bedding-parallel foliation, and the second - not as easily observed - is perpendicular to the first and created interference patterns [20], [25], [26]. The sulphide which appears with the Supergene deposits in the area has a volcanogenic nature as a part of the Ariab Proterozoic greenstone belt. Theses sulphide deposits behave such as protores that underwent subsequent enrichment by weathering the SBR deposits creation. The geologic setting for this feature shows the typical grade, VMS geological features and the supergene alteration mineralogy. The gossans in these deposits usually behave like vaults. However, the appearance of the quartz veins, veinlets, stockworks or vein selvages is associated with the gold-bearing quartz. On the other hand Ganaet deposit consist of stratabound goldrich barite lenses, but lacks any spatial association with underlying VMS mineralization and is not marked by well-developed gossan zones.

\section{Materials and methods}

\subsection{Remote sensing data}

Landsat 8 is the new product from NASA under Landsat open source series which has been launched in February 2013. Landsat 8 image has 11 bands; 5 in the visible and Near-Infrared (VNIR), 2 in the Thermal Infrared (TIR) region of the electromagnetic spectrum, 2 in the SWIR region, 1 in Pan Region and 1 panchromatic channel (band 8). Spatial resolution is $15 \mathrm{~m}$ for the panchromatic band, $30 \mathrm{~m}$ for VNIR and SWIR bands, and $100 \mathrm{~m}$ for the TIR bands. Two additional bands represent the different between Landsat8 and the previous product (Landsat ETM+), a deep blue coastal / aerosol band and a shortwave-infrared cirrus band [27], [28]. The image which has been used in this study (latitudes $18^{\circ} 40^{\prime} 33^{\prime \prime}$, and longitudes $35^{\circ} 36^{\prime} 39^{\prime \prime}$ ) was downloaded from US Geological Survey (USGS) website. This image (cloud free) was captured on 21 of May 2013 according to USGS website. The image contains Ariab mining district in Red Sea Hills, Sudan in zone 36N (WGS84 datum).

\subsection{Image processing techniques}

The remote sensing approaches were used on the image in order to show spectral characteristics of the study area in term of lithological mapping and hydrothermal alteration zones. The preparation and enhancement of the image was done by contrast stretching method, this Image processing methods are designed to transform multispectral image data format into an image display that either increases contrast between interesting targets and the background or yields information about the composition of certain pixels in the image [29], [25]. Color composite, band ratio, principle component analysis (PCA) and minimum noise fraction (MNF) were used in this study.

\subsubsection{Color composite}

The creation of false color composite is based on known spectral properties of rocks and alteration minerals in relation to the selected spectral bands. In this study 3 color composites were generated for the purpose of lithological and alteration zones mapping. Clay and carbonate minerals have absorption features from 2.1 to 2.4 um and reflectance from 1.55 to $1.75 \mathrm{um}$. Two combinations were used in this study to map iron oxides and clay minerals, (band 2, band 5 and band 7 as RGB) (Fig 2) and (band 6, band 5 and band 7 as RGB) (Fig 3). For silicate detection a color composite image was made using band 10, band 11 and band 7(Fig 4), which contain tow thermal bands and one SWIR band. In this combination Silicate minerals can be identified due to their characteristics of higher emissivity in the region between 10.30 and $11.70 \mathrm{um}$. 


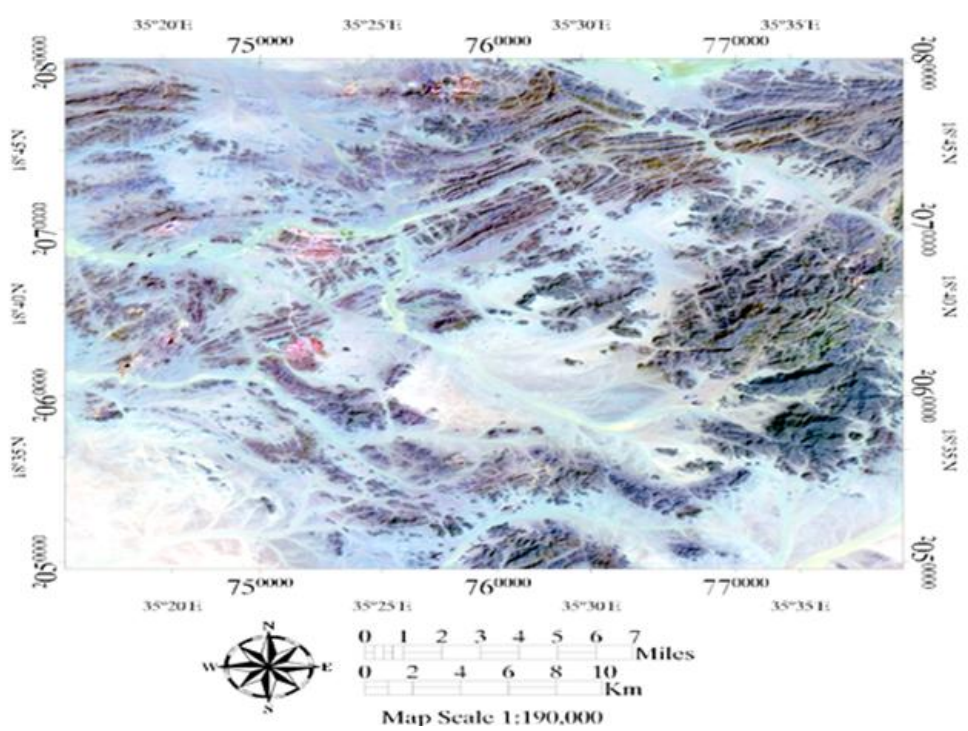

Fig. 2: Band2, Band5 and Band7 as RGB

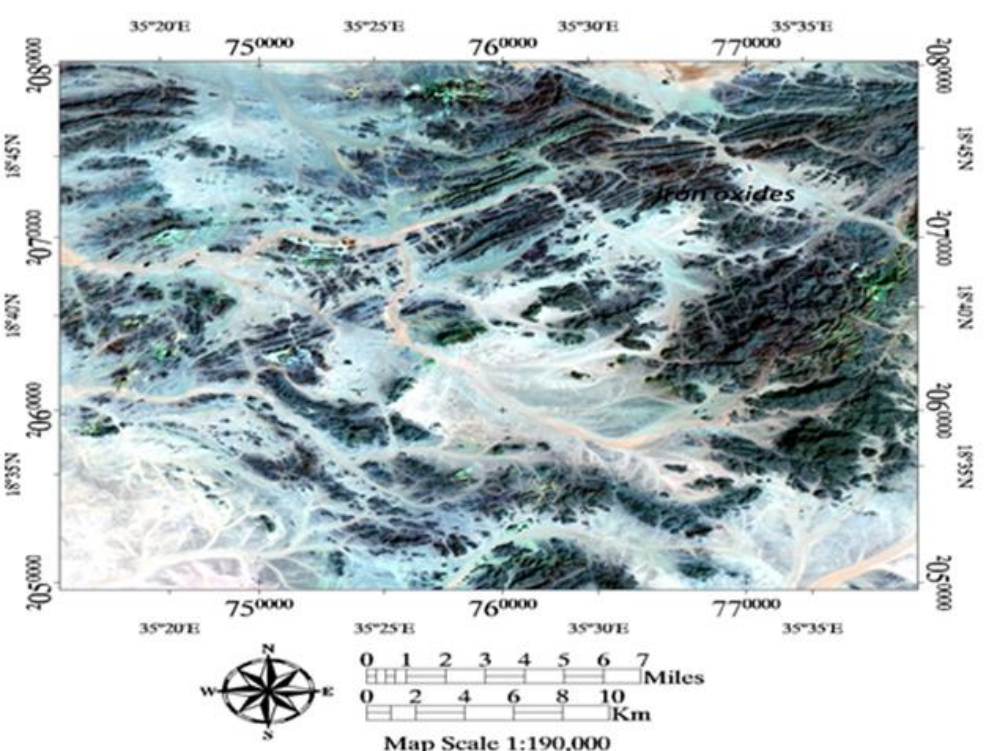

Fig. 3: Band5, Band6 and Band7 as RGB

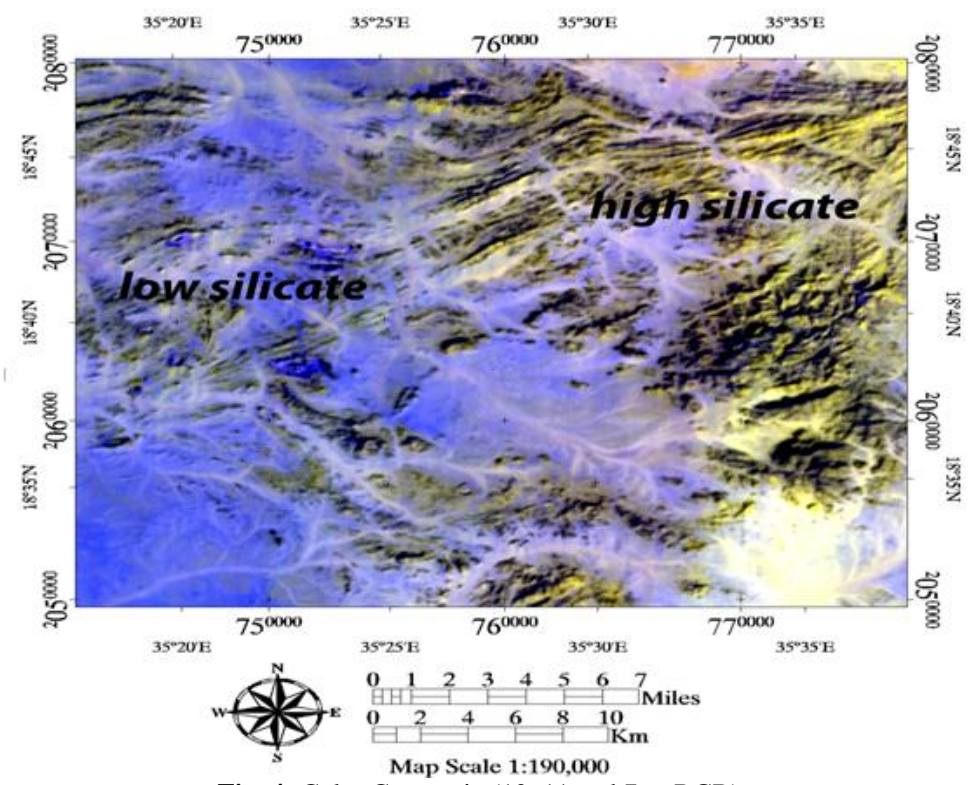

Fig. 4: Color Composite(10,11 and 7 as RGB). 


\subsubsection{Band ratio}

Band Ratio images improve the contrast between the features by divide the brightness values at peaks and troughs in a reflectance curve, after removing the atmospheric conditions from the image such as haze. Spectral band rationing enhances compositional information while suppressing other types of information about earth's surface. This method is very useful for highlighting certain features or materials that cannot be seen in the raw bands. Band ratio transformation is useful for qualitative detection of hydrothermal alteration minerals [30], [31], [32], [33].

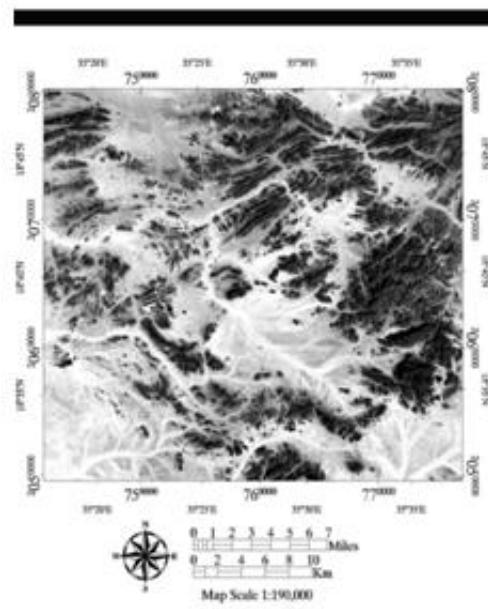

a. band ratio $4 / 2$.

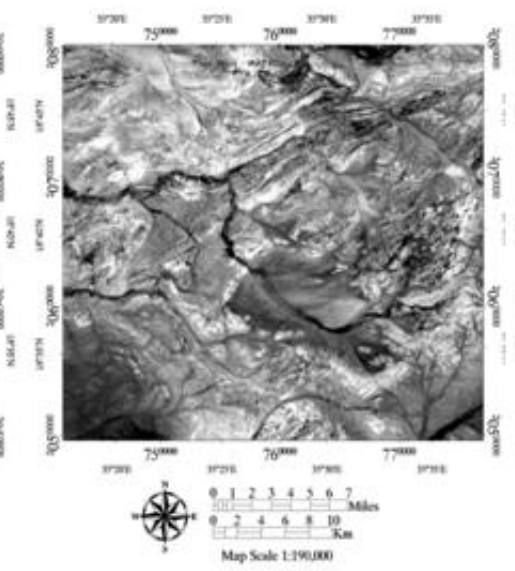

b. band ratio $6 / 5$.

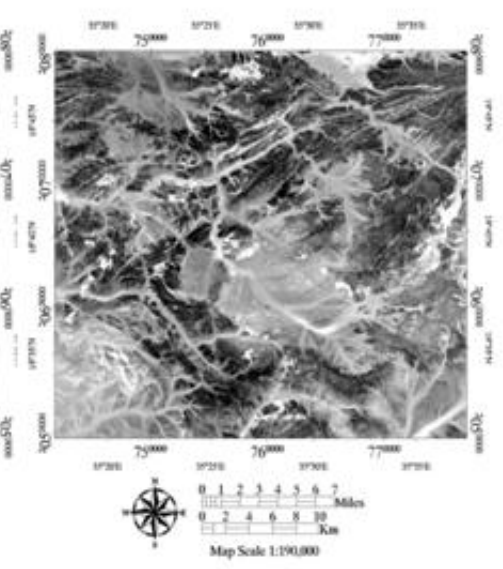

c. band ratio $6 / 7$.

Fig. 5: The Result from Band Ratio Tachnique

The ratio 4/2 (fig 5 a) is useful for mapping iron oxides because it has absorption in the blue region, where it has a high reflectance in the red region. The ratio 6/7 (Fig $5 \mathrm{c}$ ) was used in this study for its ability to map kaolinite, montmorillonite and clay minerals. All these features have a high reflectance on band 6 and low reflectance in band 7 of Landsat 8 image. The ratio 6/5 (Fig 5 b) was used for mapping ferrous minerals due to the high reflectance of these minerals in this ratio [29]. Tow combinations of RGB images have been used for lithological mapping and hydrothermal alteration zones which they called Sabins's ratio (4/2, 6/7 and band 10 as RGB and 4/2, 6/5 and 6/7 as RGB) (Fig 6) [1], [25].
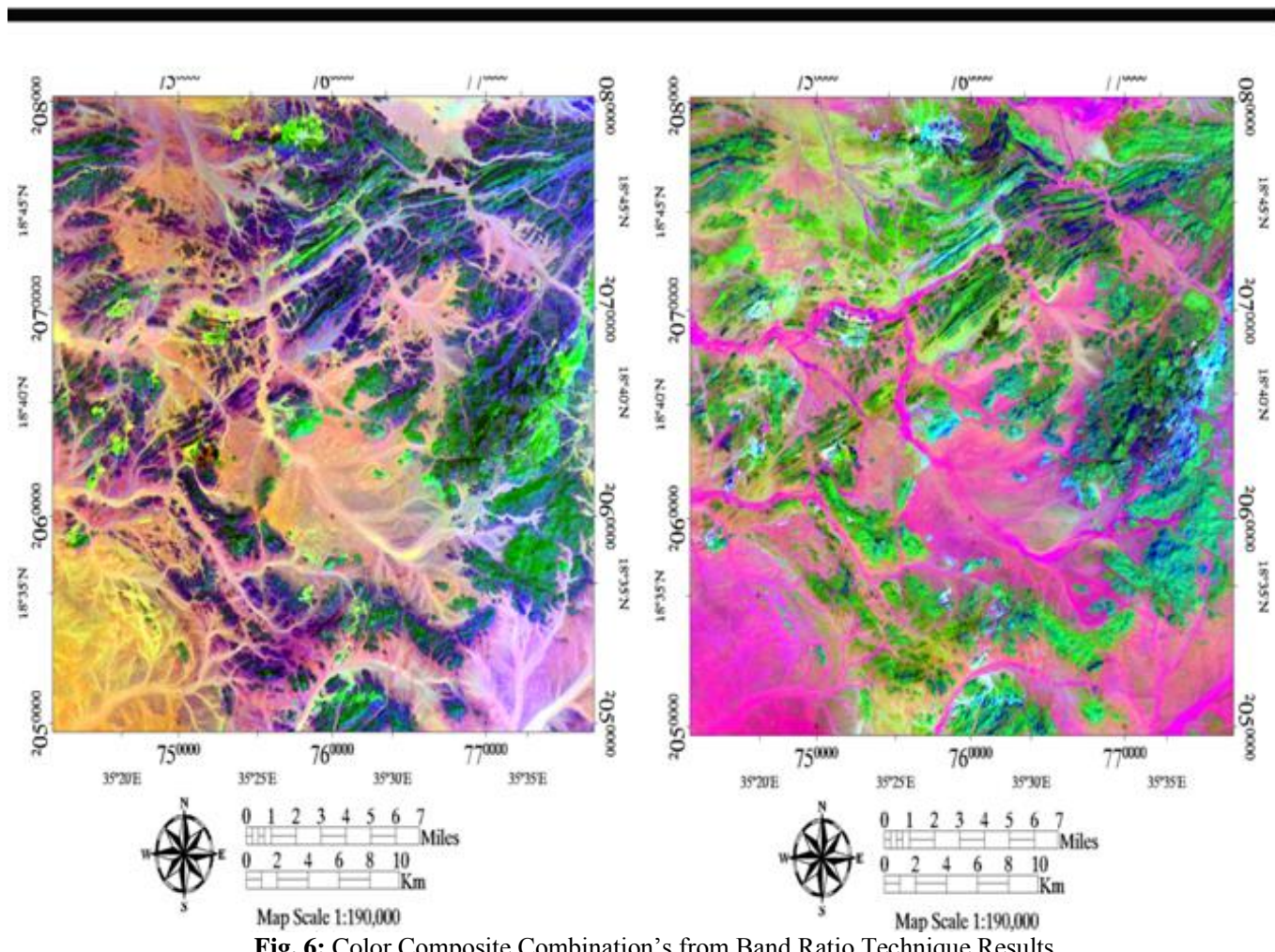

Fig. 6: Color Composite Combination's from Band Ratio Technique Results 


\subsubsection{Principle component analysis (PCA)}

PCA is a multivariate statistical technique used to reduce the data redundancy by transforming the original data onto new principal component axes producing an uncorrelated image, which has much higher contrast than the original bands [34], [35].

Table 1: The Eigenvector Matrix for the PCA Result.

\begin{tabular}{llllll}
\hline Eigenvercot & Band1 & Band 2 & Band 3 & Band 4 & Band 5 \\
\hline Band1 & -0.19564 & -0.19472 & -0.21355 & -0.24986 & -0.28691 \\
Band2 & 0.55659 & 0.48864 & 0.26452 & -0.0017 & -0.15096 \\
Band3 & 0.12584 & 0.194903 & 0.27965 & 0.32976 & 0.34206 \\
Band4 & 0.53352 & 0.37069 & 0.14981 & 0.00298 & -0.42321 \\
Band5 & -0.19904 & -0.21833 & -0.25553 & -0.29344 & -0.33595 \\
Band6 & 0.14799 & 0.11044 & 0.06711 & 0.10720 & 0.43665 \\
Band7 & -0.02037 & 0.16774 & 0.35133 & 0.35910 & -0.35430 \\
Band8 & -0.15320 & -0.24823 & 0.00437 & 0.36734 & 0.05034 \\
Band9 & -0.19387 & -0.16339 & 0.31206 & 0.39544 & -0.49195 \\
Band10 & 0.34935 & 0.012557 & -0.73835 & 0.539563 & -0.13408 \\
Band11 & -0.59904 & 0.74812 & -0.24253 & -0.01833 & 0.06147 \\
\hline
\end{tabular}

\begin{tabular}{lllllll}
\hline Eigenvercot & Band 6 & Band 7 & Band 8 & Band 9 & Band 10 & Band 11 \\
\hline Band1 & -0.32843 & -0.30438 & -0.22435 & -0.08357 & -0.50740 & -0.46706 \\
Band2 & -0.36266 & -0.34381 & 0.19498 & 0.24757 & -0.09629 & -0.01841 \\
Band3 & 0.30743 & 0.22348 & -0.54189 & -0.45178 & -0.54791 & -0.61839 \\
Band4 & -0.46293 & 0.34893 & -0.15546 & 0.12705 & -0.48154 & -0.46715 \\
Band5 & -0.31135 & -0.22940 & -0.51969 & -0.47834 & -0.58725 & -0.65872 \\
Band6 & -0.20826 & -0.83209 & 0.08207 & 0.12920 & -0.00336 & -0.00605 \\
Band7 & -0.26575 & -0.29003 & -0.57658 & 0.325700 & 0.01495 & 0.00436 \\
Band8 & -0.53702 & 0.35661 & -0.03503 & 0.600346 & 0.005439 & -0.01305 \\
Band9 & 0.450496 & -0.37673 & -0.05231 & -0.00542 & 0.303795 & 0.002702 \\
Band10 & 0.06386 & -0.07491 & -0.11705 & 0.01028 & 0.00259 & -0.00317 \\
Band11 & 0.01245 & -0.00386 & -0.00530 & -0.00102 & 0.13532 & 0.00149 \\
\hline
\end{tabular}

The result of this method was 11 uncorrelated PC bands. According to Crosta [36] the first three PC bands can be used for lithological mapping purposes, where PC1 contains most of the data variability, dominated by brightness differences caused by variation of surface topographic slope directions, with respect to the sun position, and often displays important structural information, PC2 contains the second most variability, and is orthogonal to PC1 in (n) directional space and PC3 contains the third most variability and is orthogonal to the other two PCs [30]. PC2, PC3 and PC4 (Fig 7) from Landsat 8 image were the best bands for mapping iron oxides and clay minerals from PCA result, the table ( Table 1) represent the eigenvectors of the PC bands. For the purpose of lithological mapping a color composite image was made using PC2, PC3 and PC4 as RGB.

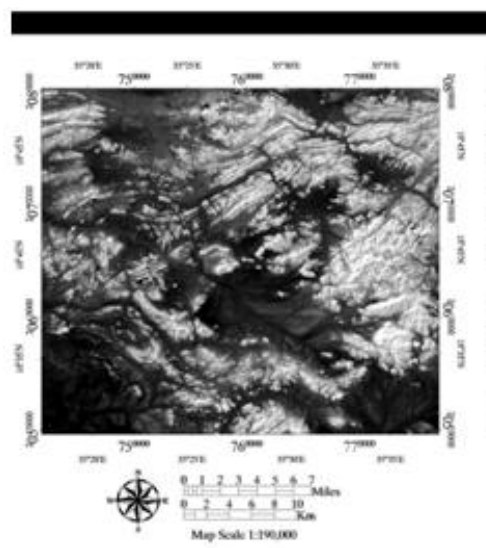

a. PC 2 image.

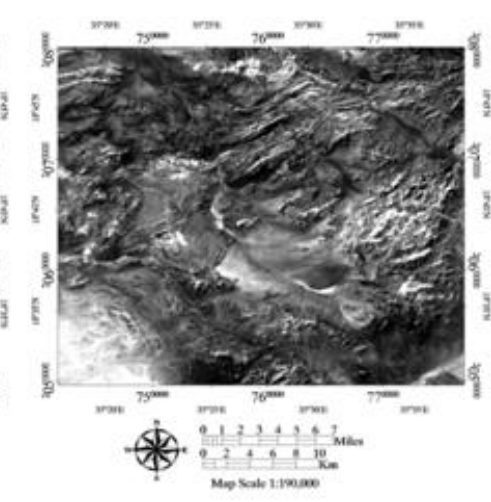

b. PC3 image.

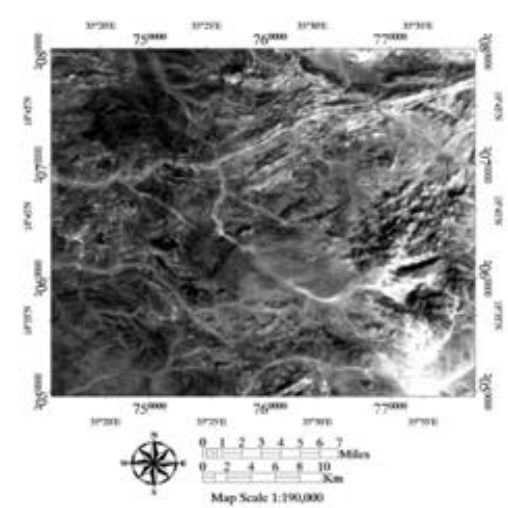

c. PC 4 image.

Fig. 7: Principle Component Analysis (PCA) Results 


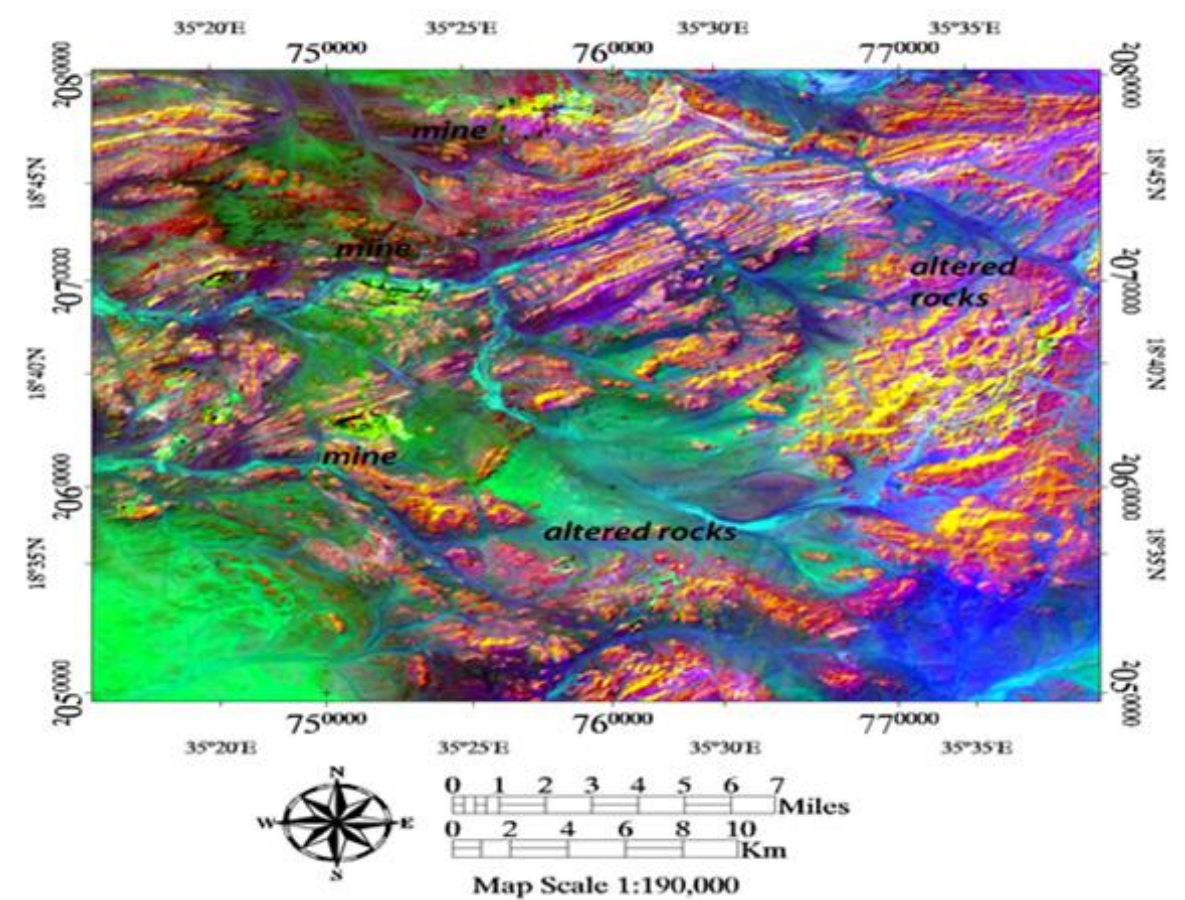

Fig. 8: Color Composite (PC2, PC3 and P as RGB)C

\subsubsection{Minimum noise fraction (MNF)}

MNF transformation can recognize the areas of otherworldly signature anomalies. This methodology is the investment to investigate geologist in light of the fact that ghastly oddities are frequently demonstrative of adjustments because of hydrothermal mineralization [33], [37]. It is utilized to figure out the intrinsic dimensionality of image information, isolate commotion in the information, and decrease the computational necessities for ensuing handling [38], [39]. Includes two steps; first and foremost, which is additionally called noise whitening, principal components for clamor covariance lattice are figured; this step decorrelates and rescales the noise in the information. In the second stage, the key parts are inferred from the noise whitened information. The information can then be separated into two parts: one part connected with extensive eigenvalues and the other part with close solidarity eigenvalues and commotion commanded images. Utilizing information with extensive eigenvalues differentiates the noise from the information, and enhances phantom outcomes [38]. This technique was used to identify hydrothermally altered rocks in the image with the help of density slice technique. The eigenvalues of the bands was described in the table (Table 2), from it band 7 , $8,9,10$ and 11 contain high noise because of the law eigenvalues these bands have.

Table 2: The Eigenvalue for the MNF Bands Result.

\begin{tabular}{ccc} 
Table 2: The Eigenvalue for the MNF Bands Result. & Percentage\% \\
\hline MNF BANDS & Eigenvalues & $54.535 \%$ \\
Band 1 & 363.0786548 & $21.248 \%$ \\
Band 2 & 148.6702149 & $10.386 \%$ \\
Band 3 & 58.95472318 & $8.075 \%$ \\
Band 4 & 48.25793648 & $2.81 \%$ \\
Band 5 & 9.96317855 & $1.089 \%$ \\
Band 6 & 5.45782394 & $0.564 \%$ \\
Band 7 & 3.08725697 & $0.471 \%$ \\
Band 8 & 2.97258431 & $0.357 \%$ \\
Band 9 & 2.14796358 & $0.291 \%$ \\
Band 10 & 1.64587215 & $0.174 \%$ \\
\hline
\end{tabular}




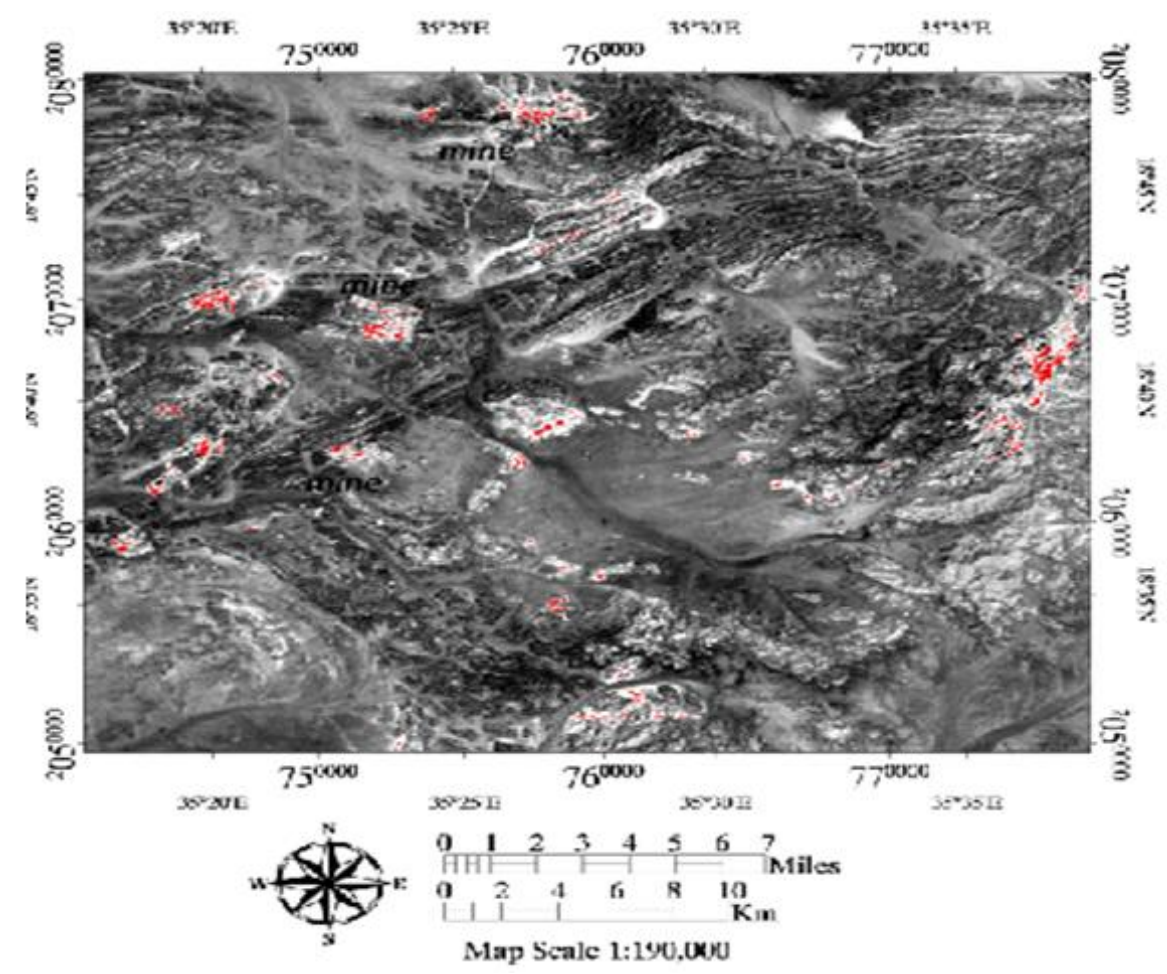

Fig. 9: Band 6 from MNF Result with Density Slice

\section{Results and discussion}

The results from color composite technique showed good results in term of lithological mapping, the images (2, 5, and $7)$ and $(6,5$ and 7$)$ showed the spectral signature of iron oxides, in which the image (10, 11 and 7$)$ showed the spectral signature and distribution of silicate. As it was seen, the iron oxides in the first composite appeared by the dark blue color in the image in Fig 2 and with the dark green in the second composite in Fig 3 due to the spectral characteristics features for iron oxides in the visible and short infrared region (VSWIR). However, Fig 4 which represents the silicate appearance image showed the feature in yellow color because of the high reflectance of the silicate in the range between 10.30 and 11.70 um.

The band ratio 4/2 rendered the areas that contain iron oxides with low DN values which appeared in Fig 5a with darker color on the image, where the places with haematitic alteration with high DN values due to the absorption of iron oxides and high reflectance of haematitic in those bands, but it was not clear enough to use this image for mapping alteration also. On the other hand the ratio 6/7 (Fig 5c) and the ratio 6/5 (Fig 5b) depict the clay alteration zones and the ferrous minerals in Ariab mining district and surrounding. The altered rocks appeared in the ratio 6/7 in Fig 6 with brighter pixels on the image due the reflectance features for the altered rocks in band 6 and absorption features in band 7 on Landsat8 image, because of that, this ratio is considered the best ratio for mapping altered rocks. 1 The combination of (4/2, 67 and band 10) and (4/2,6/5 and 6/7) (Fig 6) display the mines and the alteration zones in the area along with the other lithological units in the study area. The color composites which have been created from band ration were the best result for mapping lithological units and alteration zones

The principal component analysis (PCA) eigenvector results in Table 1 showing the values for the bands. The distribution of the lithological units in the area as shown from the results of the principal component analysis (PCA) along with the statistical results showed that PC2, PC3 was good enough for the purpose of lithological mapping, PC2 image (Fig 7a) showed the distribution of the iron oxides in the area, in which PC3 was the best image for the clay minerals. PC4 (Fig 7c) was the best band to differentiate between them. A color composite was created using PC2, PC3 and PC4 (Fig 8), which showed good result for mapping the lithological units in the study area. The image showed the 3 mines in the study area with different colors in respect of the type of mineralization in the mine as we stated in the geological setting. The alteration zones in the area also appeared in this image respectfully of the type of gold which in is there according to the spectral characteristics from the 3 mines.

The eigenvalues statistics from the minimum noise fraction (MNF) bands result displayed the amount of useful data in each band. However, the bands $(1,2,3,4,5,6)$ were the useful bands from MNF result, in which the other bands contain noise due to the less than $1 \%$ eigenvalue these bands have(Table 2). The use of the spectral signature of the mines along with the density slice technique in the minimum noise fraction (MNF) band 6 result (Fig 9), in which the high reflectance band for the clay minerals in Landsat 8 image showed the distribution of the altered rocks in the study area using one of the spectral mapping techniques. these methods are very effective and accurate in most of the time with the Hyperspectral and Multispectral images with large number of bands which the EMR divided on these bands, but in this 
study Landsat 8 image has been used which it cover the region between 0.4 to 2.5 um and has two thermal bands in 10.30 to $11.30 \mathrm{um}$ and 11.50 to $12.50 \mathrm{um}$. Unfortunately most of minerals spectral characteristic lay on the region between 2.5 to $10.30 \mathrm{um}$. Because of that in our situation this method can be used to identify the clay minerals but cannot identify the individual species of the clay minerals such as kaolinite or muscovite in separate.

The results from all the image processing approaches were more or less similar. However, the use of these techniques proved the ability of remote sensing techniques to identifies and show the high potential areas for mineralization using Landsat 8 image at regional scale.

\section{Conclusion}

The purpose from this study was to conduct an investigation using Landsat 8 data and remote sensing techniques to map the lithological units and the alteration zones in Ariab mining area and surrounding. The outcome of the remote sensing techniques such as color composite, band ratio, principle component analysis and minimum noise fraction was promising in mapping lithological and altered rocks. Color composite and Principle component analysis approaches showed the lithological units in the area. Band ratio and minimum noise fraction techniques showed the distribution of the alteration zones and the high potential areas for gold mineralization. From all the remote sensing techniques that has been used, band ratio approach showed the best result among all the others in detecting the hydrothermal altered rocks. However, the results from the remote sensing techniques of Landsat 8 image proved the ability and the role played by this data in mapping lithological units and hydrothermal alteration zones at regional sacle.

\section{Acknowledgements}

We are grateful to our families and friends for the support and Encouraging. Many thanks for Prof. Mazlan Hashim and Uiversiti Teknologi Malaysia (UTM).

\section{References}

[1] Sabins, F.F., 1999. Remote sensing for mineral exploration. Ore GeologyReviews 14, 157-183

[2] Hunt, G. (1977). Spectral signatures of particulate minerals in the visible and near infrared. Geophysics, 42, 501-513.

[3] Hunt G, R. and Ashley, P. (1979). Spectra of altered rocks in the visible and near infrared. Economic Geology, 74, 1613-1629.

[4] Clark, R.N., King, T.V.V., Klejwa, M. and Swayze, G.A. (1990). High spectral resolution reflectance spectroscopy of minerals. Journal of Geophysical Research, 95, 12653-12680.

[5] Cloutis, E.A. (1996). Hyperspectral geological remote sensing: evaluation of analytical techniques. International Journal of Remote Sensing, 17 (12), 2215-2242.

[6] Dehnavi, G. A., Srikhani, R., \& Nagaraju, D. (2010). Image procesing and analysis of mapping alteration zones in environmental research, East of Kurdistan, Iran. World Applied Sciences Journal, 11(3), 278-283.

[7] Pour, B.A., Hashim, M (2011 a). Identification of hydrothermal alteration minerals for exploring of porphyry copper deposit using ASTER data, SE Iran. Journal of Asian Earth Sciences 42, 1309-1323.

[8] Aye, F., Cheze, Y., El-Hindi, M., 1985. Discovery of a major massive sulfide province in northeastern Sudan. In: Proceedings Conference on Prospecting in Areas of Deseart Terrains, Rabat, Morocco, pp. 43-48.

[9] Cottard F, Braux C, Cortial P, Deschamps Y, El Samani Y, Hotitn, AM, and Omar Younis M. 1986. Les amas sulfurés polymétalliques et les minéralisations aurifères du district d'Ariab (Red Sea Hills, Sudan). Historique de la découverte, cadre géologique et principaux caractères des gisements. Chron. Rech. Min. no.483, pp.19-40.

[10] Bakheit, A.K., Matheis, G., 1993. Gold-productive volcanogenic sulphide mineralization in the Ariab Belt, Red Sea Hills, Sudan: Evidence for Late Proterozoic seafloor hydrothermal systems. In: Thorweiehe U., Schandelmeier, H. (Eds.), Geoscientific Reseasrch in Northeast Africa. Balkema, Roterdam, pp. 533-540.

[11] Wipfler, E.L., 1994. Geochemische, strukturelle und erzmikroskopische Untersuchungen zur Lagerstattenentwicklung des westlichen Ariab Nakasib Belt, Red Sea Provinz, NE Sudan. Berliner Geowissenschaften Abhandlungen 166, 206p.

[12] Goldsmith, R., Kouther, J.H., 1971. Geology of the Mahd adh Dhahab Umm ad Damar area, Kingdom of Saudi Arabia. Direcorate General of Mineral Resources, Kingdom Saudi Arabia Mineral Resources Bulletin 6, 20p.

[13] Abdelsalam, M. and Stern, R. (2000). Mapping gossans in arid regions with Landsat TM and SIR-C images, the Beddaho Alteration Zone in northern Eritrea. Journal of African Earth Sciences, 30(4), 903-916.

[14] Johnson PR (1994) The Nakasib suture: a compilation of recent information about a Sudanese fold and thrust belt, and implications for the age, structure, and mineralization of the Bi'r Umq suture, Kingdom of Saudi Arabia. Ministry Petrol Mineral Res, Kingdom of Saudi Arabia, Open-File Rep USGS-OF-94-6, 44 pp.

[15] Hume, W.F., 1937. Geology of Egypt, Vol. II the Fundamental Pre-Cambrian Rocks of Egypt and the Sudan, their Distribution, Age and Character, Part Ill. The Minerals of Economic Value. Government Press, Cairo, 300p.

[16] Abdelsalam,M.G., Stern, R.J., 1996. Sutures and Shear Zones in the Arabian-Nubian Shield. Journal of African Earth Sciences 23, 289-310.

[17] GRAS, 1990. Base metal in the Sudan, GRAS Rep. Sudan.

[18] Mansour (A.O.), Samuel (A.)- Geology and hydrogeology (sheet 66-A-Rashad) \& (sheet 66-E-Talodi). Geol. Surv. Dept., Reg. Geol., Mem., 1. 1957. 48p.

[19] Gabert, V. G., Ruxton, B. P. and Venzlaff, H. , 1960. Uber Untersuchungen in Kristallin der Nordlichen Red Sea Hills in Sudan, Geologisches Jahrbuch, Band 77, p. 241-270.

[20] Cottard, F. Deschamps, Y. Bernadet, G. and El Samani, Y. 1986b. Gold deposits of Ariab area. BRGM Rep. No. 86 SDN 110, Khartoum, 55p.

[21] Grove A. 2003b. Kamoeb resource estimate, pit optimization and design and reserve summary. COGEMA internal document.

[22] Abu Fatima Mohamed 2006 (Thèse Doctorat Université Poincaré Nancy) Métallogénèse et evolution géotectonique des amas sulfurés polymétalliques et des gisements d'or associés de la chaine d'Araib-Arbaat (Red Sea Hills NE Soudan). 
[23] Stern, R.A. and Lucas, S.B. 1994: U-Pb zircon age constraints on the early tectonic history of the Flin Flon accretionary collage, Saskatchewan; in Current Research 1994-F, Geological Survey of Canada, p. 75-86.

[24] Kujjo, May 2010, APPLICATION OF REMOTE SENSING FOR GOLD EXPLORATION IN THE NUBA MOUNTAINS, SUDAN,(master thesis) Bowling Green State University.

[25] El Khidir, S. O., (2006), Remote Sensing and GIS Applications in Geological Mapping, prospecting for minerals deposits and groundwater Berber Sheet Area, Northern Sudan. (Ph. D. Thesis). Al Neelain University, Khartoum, Sudan.

[26] Amireault, 2006, Technical Report N43-101 on the Hassaï Mine, Sudan. La Mancha Resources Inc.

[27] Roy et al., 2013, Turbid wakes associated with offshore wind turbines observed with Landsat 8. Remote Sensing of Environment 145 (2014), $105-115$.

[28] Vanhellemont and Ruddick, 2013, Landsat-8: Science and product vision for terrestrial global change research. Remote Sensing of Environment, 145 (2014) 154-172.

[29] Gupta, R. P. (2003), Remote sensing Geology. 2nd edition, Springer, Germany.

[30] Vincent, Robert K., 1997, Fundamentals of Geological and Environmental Remote Sensing, Prentice Hall, Upper Saddle River, NJ, pp. 80121 .

[31] Di Tommaso, I., Rubinstein, N., 2007. Hydrothermal alteration mapping using ASTER data in the Infiernillo porphyry deposit, Argentina. Ore Geol. Rev. 32, 275-290.

[32] Rockwell, B. W., Hofstra, A.H., 2008. Identification of quartz and carbonate minerals across northern Nevada using ASTER thermal infrared emissivity data Implications for geologic mapping and mineral resource investigations in well-studied and frontier areas. Geosphere 4(1), 218-246.

[33] Pour, B. A., Hashim, M (2011 b). Spectral transformation of ASTER and the discrimination of hydrothermal alteration minerals in a semi-arid region, SE Iran. International Journal of the Physical Sciences 6(8), 2037-2059.

[34] Crosta, A. P. and McM. Moore, J.: (1989), Enhancement of Landsat Thematic Mapper Imagery for Residual Soil Mapping in SW Minais Gerais State, Brazil: A Prospecting Case History in Greenstone Belt Terrain. Proceedings of the 7th (ERIM) Thematic Conference: Remote Sensing for Exploration Geology. Calgary, 2-6 Oct, pp. 11733-1187.

[35] Loughlin, W. P. (1991), Principal Component Analysis for Alteration Mapping. Photogrammetric Engineering \& Remote sensing, Vol. 57(9), pp 1163-1169.

[36] Crosta, A. P., and Rabelo, A., 1993. Assessing of Landsat TM for hydrothermal alteration mapping in central western Brazil . Proceedings of Ninth Thematic conference geologic remote sensing Pasadinea, p. 1053-61, California, USA.

[37] Pour, B. A., Hashim, M (2012 b). Identifying areas of high economic-potential copper mineralization using ASTER data in Urumieh-Dokhtar Volcanic Belt, Iran. Advances in Space Research 49, 753-769.

[38] Green, A. A., Berman, M., Switzer, P., and Craig, M. D., 1988, A transformation for ordering multispectral data in terms of image quality with implications for noise removal: IEEE Transactions on Geoscience and Remote Sensing, v. 26, no. 1, p. 65-74.

[39] Boardman, J. W., 1998, automated spectral unmixing of AVIRIS data using convex geometry concepts: in Summaries, Fourth JPL Airborne Geoscience Workshop, JPL Publication 93-26, v. 1, p. 11 - 14. 